\title{
Mapping Transactional Analysis to Clinical Leadership Models
}

Dr P Thiagarajan, Specialist Registrar, Gastroenterology and Hepatology, Nottingham University Hospitals NHS Trust, Derby Road, Nottingham, NG72UH

Professor Judy McKimm, Professor of Medical Education and Director of Strategic Educational Development, Swansea University Medical School, Swansea, UK, SA2 8PP, j.mckimm@swansea.ac.uk

The authors declare no conflict of interest.

\section{Abstract}

Leaders in today's National Health Service (NHS) face the unenviable task of reconciling rising demand, frozen resource allocation and increasing accountability. As the NHS itself stands at the nexus of an unstable political and socioeconomic landscape, its future success relies largely on its ability to nurture excellence, to encourage open communication within and across healthcare teams, and to inspire its workforce through exemplary leadership and followership. Key to these endeavours are clinicians on the 'shop floor', whose daily interactions with patients and staff help to shape prevailing culture and drive progress through quality improvement and leadership initiatives. In this article, we consider how Transactional Analysis (TA) can be incorporated into professional development to help doctors develop insight into and optimise their use of different communication styles. We propose that a working knowledge of the TA ego-state model can enhance effective communication, leadership and followership within and across healthcare teams, with a view to optimising patient outcomes and workforce interactions.

\section{Introduction}

Leaders in the NHS in 2019 face unprecedented challenges. Navigating the choppy waters of soaring service demands, austerity-driven budget cuts and increasing scrutiny from national bodies, many health service leaders have found themselves divested of autonomy and forced to 'do more with less'. This is reflected in the high turnover of executive level jobs witnessed since 2015. According to a recent survey by the King's Fund, 37\% of trusts have at least one vacant board-level executive post, with the most poorly performing trusts having shorter tenures and higher vacancy rates (Anandaciva, Ward, Randhawa \& Edge, 2018). This 'leadership churn' has severe consequences on stability, productivity and progress. Framed by a tumultuous political landscape, the future and 
sustainability of the NHS has never been less certain. Leading amidst relentless and mounting pressures requires high-quality, effective leadership at all levels, but there are huge challenges in empowering such leaders to flourish so that they can improve service delivery and patient care.

The NHS Leadership Academy reinforces that (a) a range of leadership styles and behaviours is necessary to effectively implement lasting change in the NHS, and that (b) engaging and empowering staff translates directly into better patient care (NHS Leadership Academy, 2013). This paradigm shift builds on the 2011 King's Fund report, which embraces modern philosophies of shared and distributed leadership, and rejects the more traditional styles of hierarchical and 'heroic' leadership models which have traditionally dominated healthcare delivery in the UK (The King's Fund, 2011).

The key position of doctors in 'delivering the service' means they are uniquely placed to engage with clinical and non-clinical staff, patients and other stakeholders to implement change, with a view to improving the standard and quality of healthcare. A range of leadership development activities support the closer involvement of doctors in leadership roles, aiming to provide theoretical and practical tools to help them engage others to develop positive working cultures and effect lasting change. Empowered clinical leaders can employ several strategies according to the context in which they work, to engage followers and achieve desired outcomes. Key to leading successfully in a large, dynamic and complex environment such as the NHS is connectivity (McKimm and Held, 2009). This involves actively engaging stakeholders in order to minimise disenchantment, and maximise overall participation in delivering change. The successful clinical leader therefore needs to be a highly effective communicator in a wide range of situations and contexts.

While communication skills are acknowledged as vital for all doctors, medical schools predominantly focus on strengthening doctor-patient communications, with little formal training in how to communicate effectively with other doctors, managers and health professionals. Furthermore, the influence of leadership and followership styles on communication (and vice versa) has rarely been considered in clinical management literature to date. Gaining insight into the power of one's own responses to others, situational awareness and anticipated outcomes is crucial if doctors are to be successful in collaborating with colleagues and patients, and in employing transformational leadership strategies across boundaries.

In this article, we explore how one model (the 'ego state' model) from Transactional Analysis (TA) an approach commonly used in psychotherapy and counselling - can be used to analyse and develop more appropriate communications, leadership and followership approaches and positively influence 
one's own and others' behaviours and outcomes in a clinical context.

\section{What is Transactional Analysis?}

Dr Eric Berne's theory of transactional analysis (TA) was developed during the late 1950s and 1960s. It built on psychoanalysis and Sigmund Freud's proposition that our inner states govern and can predict behaviours. Whilst TA has elements in common with psychoanalysis and its models seem deceptively simple, it is widely used in psychotherapy and counselling to help clients with a range of issues including addiction and managing relationships, as well as in education, training and supervision (McKimm and Forrest, 2010; Sivan et al 2011).

The philosophy of TA revolves around a number of key concepts (McKimm and Forrest 2010; Stewart and Joines, 1987):

1. People are essentially 'OK' - this means that I accept myself as I am and you as you are, although people can learn maladaptive behaviours which undermine this belief

2. Everyone has the capacity to think for themselves (with some exceptions)

3. People decide their own destiny, therefore decisions can be changed

4. The basic unit of interaction and communication is a 'transaction', which can be verbal or non-verbal

5. People need 'strokes' - social stimuli, recognition or attention - and positive strokes are essential for psychological well-being

From the many TA models that exist, we are going to take one of the fundamental models, the egostate model and explore how this might help and hinder communications in the clinical setting, specifically focussing on leader-follower interactions and relationships.

\section{The ego state model}

In considering how people interact with one another, themselves and the world, the 'ego state model' suggests that every individual's personality comprises three ego states: 'Parent', 'Adult' and 'Child' (Figure 1). At any given time, people may operate in any of the states, often without conscious awareness. The most helpful and productive interactions (particularly in the workplace) are those in which both parties are operating in 'Adult', using all resources available to them, being able to objectively analyse a situation, and function in the 'here and now' (i.e. they are fully present). Whilst 'Adult' is in the here and now, both the Parent and Child ego states are archaic and involve replaying behaviour, thinking or feelings from the past. Parent is about replaying things (behaviours, values, beliefs and opinions) we have learned from others in the past whereas when we are in the Child ego state, we replay needs, wants and feelings that we ourselves have experienced in the past. 
An example might be if we are crossing a road and a car comes out of a side street and we have to step back suddenly to avoid it (Adult). Whilst we processed the information quickly and rationally and made a decision what to do, we also feel shaky and shocked (in Child) as it reminded us of a similar event we have experienced or seen. At the same time, a Parental message might play in our head, for example 'you must always pay attention when you're crossing the road'.

Figure 1 The Parent-adult-child diagram demonstrating the three TA ego states

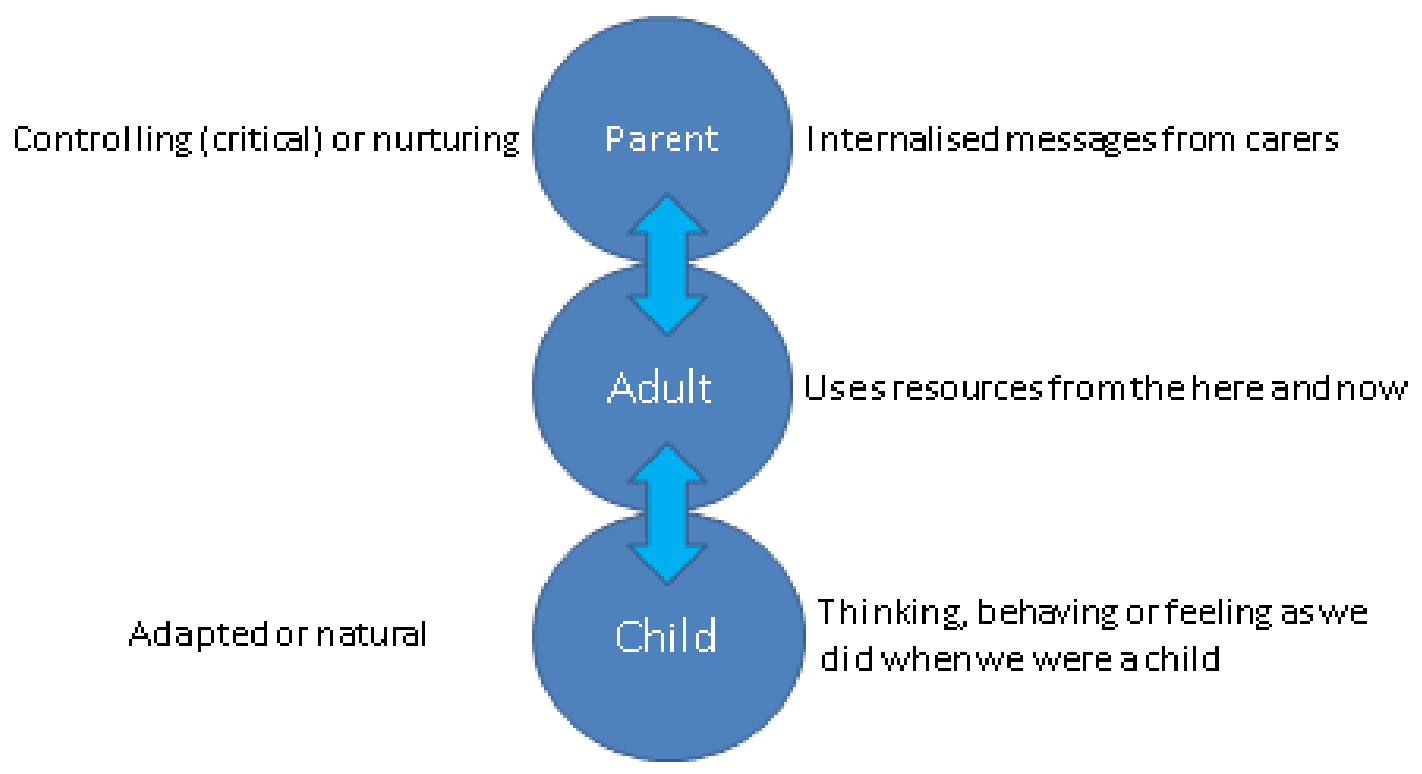

Table 1 Summary of key features of the ego states

\begin{tabular}{|c|c|c|c|c|}
\hline Ego state & Positive features & Negative features & $\begin{array}{l}\text { Verbal } \\
\text { signs/behaviours }\end{array}$ & $\begin{array}{l}\text { Non-verbal } \\
\text { signs/behaviours }\end{array}$ \\
\hline $\begin{array}{l}\text { Controlling Parent } \\
\text { Seeks to make the } \\
\text { Child do what it } \\
\text { wants them to do, }\end{array}$ & $\begin{array}{l}\text { Protective, gives } \\
\text { helpful rules and } \\
\text { boundaries to keep } \\
\text { people safe } \\
\text { e.g. transferring } \\
\text { beliefs and values, } \\
\text { helping the Child to } \\
\text { live in their society }\end{array}$ & $\begin{array}{l}\text { Critical and } \\
\text { controlling } \\
\text { May have negative } \\
\text { intent and seek to } \\
\text { punish the Child in } \\
\text { some way } \\
\text { May be seen as } \\
\text { bossy and }\end{array}$ & $\begin{array}{l}\text { 'Should', 'must', } \\
\text { 'don't', 'good', } \\
\text { 'bad' } \\
\text { Harsh, abrupt, } \\
\text { authoritative tones }\end{array}$ & $\begin{array}{l}\text { Finger pointing, } \\
\text { wagging finger, } \\
\text { arms crossed, over- } \\
\text { staring, } \\
\text { serious/stern face } \\
\text { Rolling eyes, } \\
\text { furrowed brow, } \\
\text { scowling }\end{array}$ \\
\hline
\end{tabular}




\begin{tabular}{|c|c|c|c|c|}
\hline & $\begin{array}{l}\text { Good in a crisis } \\
\text { when authoritative } \\
\text { leadership is } \\
\text { required }\end{array}$ & $\begin{array}{l}\text { overbearing } \\
\text { Coercive leadership } \\
\text { is negative for } \\
\text { organisational } \\
\text { cultures }\end{array}$ & & $\begin{array}{l}\text { Standing over } \\
\text { someone }\end{array}$ \\
\hline $\begin{array}{l}\text { Nurturing Parent } \\
\text { Seeks to keep the } \\
\text { Child contented } \\
\text { and calm their fears }\end{array}$ & $\begin{array}{l}\text { Displays caring } \\
\text { behaviours, is } \\
\text { helpful } \\
\text { Offers safety and } \\
\text { care } \\
\text { Useful for } \\
\text { affiliative, } \\
\text { developmental and } \\
\text { coaching leadership }\end{array}$ & $\begin{array}{l}\text { Over protective, } \\
\text { smothering, takes } \\
\text { over, doesn't allow } \\
\text { risk-taking or } \\
\text { others to develop } \\
\text { their own skills }\end{array}$ & $\begin{array}{l}\text { 'Don't worry', 'let } \\
\text { me help you', 'I'll } \\
\text { do it for you' } \\
\text { Soothing, consoling }\end{array}$ & $\begin{array}{l}\text { Pat on arms, hugs, } \\
\text { nodding } \\
\text { encouragingly, } \\
\text { active listening } \\
\text { Smiling, proud eyes }\end{array}$ \\
\hline $\begin{array}{l}\text { Adult } \\
\text { Our 'ideal self' } \\
\text { behaves the way } \\
\text { our 'best self' } \\
\text { would behave }\end{array}$ & $\begin{array}{l}\text { Functions in the } \\
\text { here and now, is } \\
\text { present } \\
\text { Relies on objective } \\
\text { factual data to } \\
\text { make rational } \\
\text { decisions, using } \\
\text { logical practical } \\
\text { thinking } \\
\text { Communicates } \\
\text { clearly } \\
\text { Able to respond } \\
\text { appropriately in } \\
\text { difficult } \\
\text { interactions } \\
\text { Uses feedback from } \\
\text { the Parent and }\end{array}$ & $\begin{array}{l}\text { None really } \\
\text { although might be } \\
\text { seen as boring and } \\
\text { pedantic } \\
\text { However, the Adult } \\
\text { ego state seeks } \\
\text { balance and can } \\
\text { handle fierce } \\
\text { conversations }\end{array}$ & $\begin{array}{l}\text { 'How', 'when', 'I } \\
\text { understand', tell } \\
\text { me more' } \\
\text { Calm, clear even } \\
\text { tones }\end{array}$ & $\begin{array}{l}\text { Level eye-contact, } \\
\text { absence of } \\
\text { fidgeting, } \\
\text { Open and } \\
\text { thoughtful facial } \\
\text { expressions }\end{array}$ \\
\hline
\end{tabular}




\begin{tabular}{|c|c|c|c|c|}
\hline & $\begin{array}{l}\text { Child ego states } \\
\text { Can tap into and } \\
\text { utilise a wide range } \\
\text { of relevant } \\
\text { leadership } \\
\text { approaches }\end{array}$ & & & \\
\hline $\begin{array}{l}\text { Natural Child - } \\
\text { Free Child } \\
\text { Unencumbered by } \\
\text { rules and what you } \\
\text { 'should do' }\end{array}$ & $\begin{array}{l}\text { Responds with } \\
\text { natural emotions to } \\
\text { the world around } \\
\text { you, likes playing } \\
\text { Displays genuine } \\
\text { feelings - positive if } \\
\text { appropriate to the } \\
\text { situation (e.g. } \\
\text { crying when } \\
\text { someone dies) } \\
\text { Can offer } \\
\text { spontaneity to the } \\
\text { team and shows } \\
\text { authentic } \\
\text { leadership }\end{array}$ & $\begin{array}{l}\text { Displays genuine } \\
\text { feelings - negative } \\
\text { if inappropriate to } \\
\text { situation (e.g. } \\
\text { crying in a formal } \\
\text { meeting) } \\
\text { May be seen as } \\
\text { over-emotional, } \\
\text { naïve or immature } \\
\text { Open and } \\
\text { potentially } \\
\text { vulnerable }\end{array}$ & $\begin{array}{l}\text { 'I wish', 'I want', } \\
\text { 'wow', 'love', 'hate' } \\
\text { Makes non-speech } \\
\text { noises } \\
\text { Joyful, noisy, } \\
\text { energetic tones }\end{array}$ & $\begin{array}{l}\text { Exaggerated } \\
\text { movements, } \\
\text { uninhibited } \\
\text { Bright-eyed, smiling } \\
\text { freely } \\
\text { Joking }\end{array}$ \\
\hline $\begin{array}{l}\text { Natural Child - } \\
\text { Little Professor } \\
\text { Has natural } \\
\text { curiosity in order to } \\
\text { solve problems }\end{array}$ & $\begin{array}{l}\text { Curiosity, creativity } \\
\text { and source of ideas, } \\
\text { always trying new } \\
\text { things } \\
\text { Creativity and } \\
\text { openness to } \\
\text { experience are } \\
\text { valuable leadership } \\
\text { and followership } \\
\text { skills }\end{array}$ & $\begin{array}{l}\text { May get distracted } \\
\text { and be seen as } \\
\text { being unable to } \\
\text { focus or stick to } \\
\text { one thing } \\
\text { Uses resources and } \\
\text { problem solving } \\
\text { mechanisms from } \\
\text { the past rather } \\
\text { than the here and } \\
\text { now }\end{array}$ & $\begin{array}{l}\text { 'I wonder why', 'I } \\
\text { wonder how', 'I } \\
\text { wonder what if ...' }\end{array}$ & $\begin{array}{l}\text { Uses words, } \\
\text { diagrams and } \\
\text { models to explain } \\
\text { the world } \\
\text { Appears quick- } \\
\text { thinking }\end{array}$ \\
\hline Adapted Child - & Reacts to the world & Might try to change & 'Yes of course', & Avoids eye contact, \\
\hline
\end{tabular}




\begin{tabular}{|c|c|c|c|c|}
\hline $\begin{array}{l}\text { Compliant Child } \\
\text { Learned to do what } \\
\text { they were told, to } \\
\text { be accepted and fit } \\
\text { in }\end{array}$ & $\begin{array}{l}\text { around them and is } \\
\text { very aware of social } \\
\text { rules and norms } \\
\text { Tries hard to please } \\
\text { others and } \\
\text { compromise } \\
\text { When leaders are } \\
\text { respected will be a } \\
\text { good follower }\end{array}$ & $\begin{array}{l}\text { themselves to fit in } \\
\text { (e.g. gender } \\
\text { stereotypes) and } \\
\text { become inauthentic } \\
\text { Might be subject to } \\
\text { feeling criticised, } \\
\text { left out or try to } \\
\text { over-please, } \\
\text { Can seem under- } \\
\text { confident, unable } \\
\text { to accept } \\
\text { responsibility, } \\
\text { unassertive and } \\
\text { become a 'victim' }\end{array}$ & $\begin{array}{l}\text { 'Please', 'sorry', } \\
\text { 'may I?', 'I'll try' }\end{array}$ & $\begin{array}{l}\text { appears hyper- } \\
\text { aware of what } \\
\text { everyone is doing } \\
\text { and saying, } \\
\text { appeasing smile, } \\
\text { nodding } \\
\text { Downcast } \\
\text { expression }\end{array}$ \\
\hline $\begin{array}{l}\text { Adapted Child - } \\
\text { Rebellious Child } \\
\text { Fights back as a } \\
\text { protective device to } \\
\text { avoid being hurt or } \\
\text { ignored }\end{array}$ & $\begin{array}{l}\text { Able to gain } \\
\text { attention from } \\
\text { others } \\
\text { Can be used when } \\
\text { strong, } \\
\text { competitive, } \\
\text { forceful leadership } \\
\text { is required }\end{array}$ & $\begin{array}{l}\text { Can appear } \\
\text { attention-seeking, } \\
\text { argumentative, } \\
\text { aggressive or } \\
\text { rebellious - an } \\
\text { 'alienated' follower } \\
\text { Can be disruptive }\end{array}$ & $\begin{array}{l}\text { 'I can't', 'I won't' } \\
\text { Complaining, surly } \\
\text { or aggressive tones } \\
\text { Non-speech noises } \\
\text { e.g. huffing, sighing, } \\
\text { rusting papers }\end{array}$ & $\begin{array}{l}\text { Fidgeting, slouching } \\
\text { Pouting expression, } \\
\text { withdrawal (with } \\
\text { 'noises off') } \\
\text { Acts out for } \\
\text { attention }\end{array}$ \\
\hline
\end{tabular}

The effectiveness of a particular interaction depends on whether transactions are parallel or complementary (e.g. 'Adult' to 'Adult', 'Parent' to 'Child'). If one party directs a statement to the other operating from either 'Parent' or 'Child' mode, the recipient may answer in kind, rather than maintaining an effective 'Adult' character. What happens when such transactions occur, is that if we feel that someone is operating from (for example) 'controlling Parent', we start to feel like we did when we were a child. So if we feel someone is critical of us or they are trying to boss us about, then we may start functioning from an 'adapted Child' ego-state and find ourselves becoming overcompliant, rebellious or argumentative. Another example is if we feel lacking in confidence or that we don't belong to a team, we might appear to others that we are operating from the 'Child' state and they might go into 'Parent'. This might be positive in that they start helping us or giving us hints 
and tips about the team, but it could be negative and they might start over-protecting us or criticising us.

These 'Parent' - 'Child' transactions could continue indefinitely, but in most situations (and certainly in the workplace), it is much better to recognise this and for both parties to move into the 'Adult' ego state. We do this primarily by recognising how we feel and what we are thinking: often just starting to think about what is going on helps us make the transition into 'Adult' as we are moving from a 'feeling' to 'thinking' state. Strengthening the ability of a person to operate primarily in 'Adult' and to draw from the other ego states appropriately is one of the main goals of TA. A final point to make is that, when we are structurally operating from the 'Adult' ego state, we can to choose to function as if we are in either 'Parent' or 'Child', but we are not actually in those ego states even if the other person responds to us as if we are. From Adult, we can help people (but we won't take over their problem-solving), give negative feedback (but constructively, not in a punishing way) and be assertive (e.g. say no to things we don't want to do). So even if the other person goes into 'Child' (e.g. becomes upset or argumentative), from 'Adult', we can make sure that they are psychologically safe, as we are operating with all our resources in the here and now. Gradually, through staying in 'Adult' (using calm tones, acknowledging their feelings, staying rational and logical, and maintaining eye contact) we can help the person move back into their 'Adult' and become re-engaged.

When practising TA, a contract is usually established, which is rooted in open communication and in which both parties are fully aware of their tasks, taking joint responsibility towards achieving their goals. TA highlights the importance of effective communication in achieving any goal, and facilitates the development of both emotional and intellectual insight. However, very few doctors have formal training in TA or its impact on communication styles and leadership philosophies.

\section{Leadership Lessons}

In this section, drawing from Weihrich's (1979) and our own work (McKimm and Forrest, 2010), we consider the ego-state model in relation to leadership and followership styles, and explore how a working knowledge of the ego states can enable the leader and follower to employ a range of strategies according to the demands of a particular situation, individual or group. Figure 2 sets out some of the predominant leadership and followership approaches and relates them to the egostates. For reasons of space we cannot go into detail of all these approaches, but these range from the traditional 'hero leader' to the more contemporary approaches suggested as appropriate for 
healthcare such as compassionate and caring leadership (see for example King's Fund 2011 and West et al 2017).

In the Emergency Department (ED), whilst many clinicians undertake leadership of various situations, medical leadership falls mainly to consultants and registrars, who guide more junior doctors in training in their decision-making, and oversee safe management of patients. In the following scenarios, two doctors in training reflect on real-life interactions with senior colleagues and we map these communications and leadership approaches onto the ego-state model.

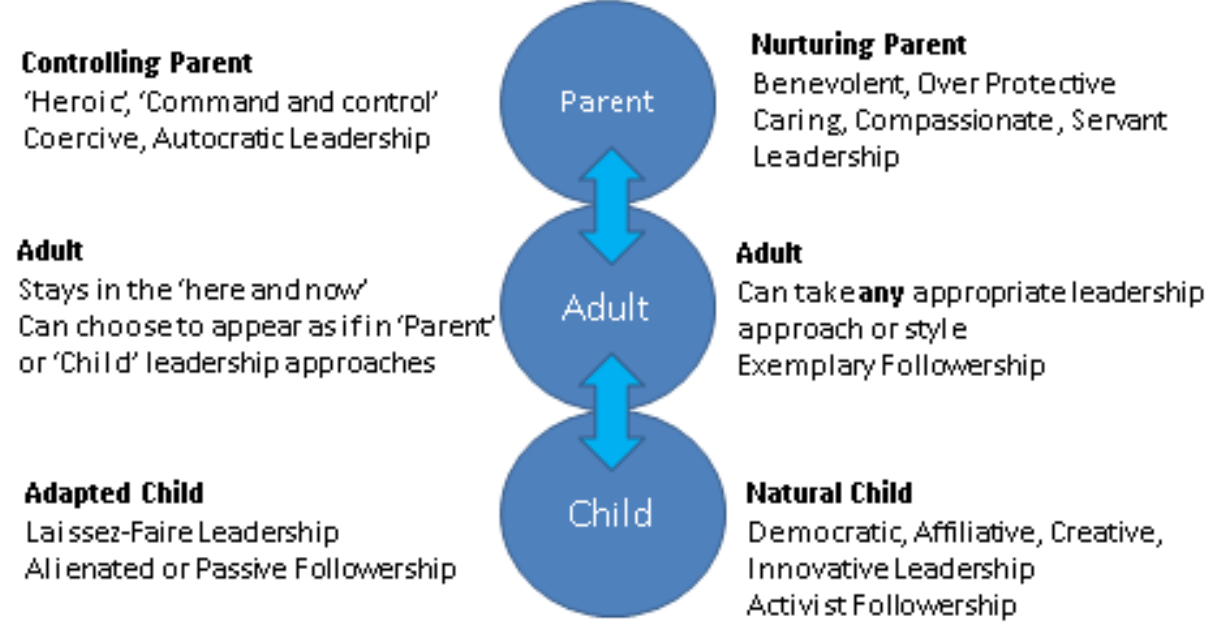

Figure 2. Mapping of TA Ego States to leadership and followership approaches and styles

Both an autocratic ('command and control') and a benevolent leadership style can be seen as operating primarily from the 'Parent' ego state; reflecting the 'controlling' and 'nurturing' parent ego-states respectively.

In contrast, individuals functioning from the 'Adult' ego state are able to provide productive leadership, through encouraging collaboration, inviting questions and considering the opinions of followers within the organisation. The 'Adult' leader is democratic (consultative) and affiliative (aligning people to achieve goals), and can gather information to accurately assess a particular 
situation. They would facilitate good communication through empowering team members, demonstrating individualised consideration (Bass and Avolio, 1994), and hence encouraging both vertical and horizontal discussion, i.e. between seniors (leaders) and subordinates (followers), and between the followers themselves. Ultimately, this leadership style is integrated and conducive to improved performance as it 'encourages problem solving and decisions based on objective facts' (Weihrich, 1979). Finally, permissive or 'laissez-faire' leaders operate predominantly from a 'Child' ego state in which freedom but little authority is afforded to their followers. While this may engender an environment in which creative ideas can flourish, the lack of authority, stimulus and direction from such a leader means that these ideas fail to be implemented effectively (Weihrich, 1979).

\section{Example 1: Parent ego state and leadership styles}

$\operatorname{Dr} \mathrm{Y}$ is a Consultant Emergency physician in a large teaching hospital in the United Kingdom. With several years of experience in a range of medical specialties, he is regarded as one of the most senior doctors in the department. However, when giving advice to junior doctors, his style is often abrupt, authoritative and dismissive, such that the general level of trust in him is less than might be expected for someone of his status, knowledge and clinical acumen.

The following is an example of a dialogue between $\operatorname{Dr} \mathrm{Y}$ and $\operatorname{Dr} \mathrm{Z}$, a doctor in training working in the emergency department (ED).

$\operatorname{Dr} Z$ : $\operatorname{Dr} Y, I$ wondered if you could help me to confirm my $X$-ray findings for an 89 year old lady who fell over today and is non-weight bearing?

$\operatorname{Dr} \mathrm{Y}$ agrees to look at the $\mathrm{X}$-rays, and after a few seconds, points out:

"Dr Z, Don't tell me you can't see that pubic ramus fracture, it's blindingly obvious! A medical student would be able to diagnose this, and you've been working in my department for 6 months.

$\operatorname{Dr}$ Z: But I knew-

Dr Y: Do some homework before you present to me next time and don't interrupt when I'm talking to you.

The consultant, via his use of the 'Parent' state, had perhaps unknowingly set the stage for a 'Childlike' response from the junior doctor. Dr Y, through his critical 'Parental' response, did not permit Dr $Z$ to cross his transaction and move them both into 'Adult', where they could have a meaningful, productive discussion and work together for the good of the patient. When people are stressed and 
busy, they often move into 'Parent' (becoming abrupt and critical in this case) or 'Child' (feeling 'told off', overwhelmed or a passive follower). The leadership in this case was autocratic, commanding and pace-setting (setting high standards for self and others), as the consultant gave orders and implied that $\operatorname{Dr} Z$ had not met his standards for X-ray interpretation. There was little opportunity given for a participative or inclusive approach in this case. Had the consultant offered $\mathrm{Dr} Z$ a chance to interpret the X-ray himself, he may have arrived at the correct diagnosis without being criticised, which would have resulted in a more satisfactory interaction, even a learning experience.

\section{Example 2: Adult Ego State and Leadership Styles}

One doctor in training ( $\operatorname{Dr} S$ ) in the same ED recounts her experience of leadership from the 'Adult' ego state during a trauma scenario in the ED Resuscitation room. Dr S was on a night shift with $\operatorname{Dr} J$, a registrar, when a trauma call was received about a 27 -year old man involved in a motorcycle accident, who had sustained multiple traumatic injuries.

Dr S recalls, "The patient was wheeled in on a spinal board, and was drowsy, with evidence of facial trauma. My registrar took care of the airway and ventilation, and I concentrated on obtaining largebore intravenous access, and drawing bloods. A full top-to-toe examination was conducted by my registrar, who asked me to re-examine the patient 5 minutes later and confirm her initial thoughts. She described a scalp haematoma and a compound fracture of the patient's left tibia, which orthopaedic surgeons were dealing with. I had arranged for the patient to have a computerized tomography (CT) scan of the brain, to exclude any intracerebral bleeding. My registrar arranged for the anaesthetics team to review the patient in the ED.

While I was assessing the patient, he abruptly stopped talking, and began to lose his airway. I immediately provided a temporary airway adjunct and applied an oxygen mask. Looking at his pupils, I could see that the left was far larger than the right, and did not react to light. I then glanced at the patient's observations chart, which demonstrated a rising blood pressure and falling heart rate: in short, all the signs of rapidly rising intracranial pressure. I called my registrar immediately, who confirmed my findings. I told her that I was concerned about the possibility of an extradural haematoma compressing the patient's brain. My registrar considered this and agreed. $\underline{\text { Together, we }}$ rushed the patient to the CT scanner, where an accelerated CT Head scan showed us a left-sided extradural haematoma.

We contacted the nearest Neurosurgical service immediately, and the patient was accepted for transfer. My registrar intubated the patient and ensured the presence of an anaesthetist for transfer. 
We stabilised the patient together in Resus, and he was taken by blue-light ambulance to our local neurosurgery centre. At every step, my registrar would ask for my opinion and consider it carefully. Despite being far more senior than I was, she treated my concerns with credibility and respect. She effectively involved nursing staff and relevant medical teams through constant and respectful communication, asking for ideas and taking charge effectively but not enforcing her authority.'

In this scenario, it is clear that the registrar and junior doctor worked collaboratively and with compassion to ensure all steps were taken to maximally stabilise the patient, and involve the correct medical teams. There was also distributed leadership, where power was spread across teams, e.g. nursing staff, anaesthetists, neurosurgeons and the ED physicians themselves. There is evidence of good communication, with relevant services being involved early in the patient's journey to secure best possible outcome. The registrar appears to take a democratic view on leadership, as she takes the junior doctor's viewpoint into account, treating them with credibility and respect, and encouraging active, engaged followership (Kellerman 2008; Kelley 2008).

Operating in 'Adult' ego state, $\operatorname{Dr} \mathrm{S}$ and $\operatorname{Dr} \mathrm{J}$ were able to engage in mutually beneficial interactions, working collaboratively to confirm each other's findings and ensure the highest possible level of patient care. In 'Adult', leaders are able to select appropriate leadership styles. Here Dr J chose democratic, affiliative, collective and person-centred styles as her main approaches, however, she could also take an authoritative approach when a serious decision had to be made. Through giving followers the freedom to identify problems and participate in delivering a solution, the democratic, inclusive leader employs 'Adult' style communication strategies, asking probing questions and giving credence to new ideas. Through encouraging participation, such leadership behaviours can forge consensus amongst followers and engage them in contributing towards a shared vision, as the organisation is seen as interlocking and interdependent. This also reflects Bass and Avolio's (1994) transformational leadership philosophy which focuses on raising followers' aspirations and achievements through idealised influence (role modelling) and inspiring and motivating others.

\section{Conclusions}

A working knowledge of TA models can significantly enhance communications between doctors and other health care professionals, with practical applications on the 'shop floor'. Understanding the way ego-states affect interactions can help us identify why some interactions work well and others do not. The mapping of TA to various leadership styles is a novel concept which aims to enhance the applicability of TA to various clinical situations. The examples above highlight that leaders are most effective when in 'Adult', where they can select an appropriate leadership approach, and the consequences for followers (and ultimately on patient care) when leaders operate in 'Parent'. There 
is a big difference between the leader who is operating in 'Adult' and chooses to take an authoritative or 'command and control' approach when needed, to one who is in controlling 'Parent' and takes a 'heroic' autocratic stance, inappropriate for most clinical situations. However, being able to draw from nurturing 'Parent'and display compassion, care and empathy (for both patients and colleagues) is vital. The NHS is in the midst of a febrile political, social and economic climate in which doctors must embrace democratic, compassionate and collaborative leadership approaches if they are to be successful in steering the organisation towards future success.

\section{References}

Anandaciva S, Ward D, Randhawa M, Edge R (2018). Leadership in today's NHS: Delivering the impossible. London: The King's Fund. Available at https://www.kingsfund.org.uk/publications/leadership-todays-nhs (accessed on 30/11/2018)

Bass, BM \& Avolio, BJ (1994). Improving Organizational Effectiveness through Transformational Leadership. Thousand Oaks, CA: Sage Publications.

Kellerman B. (2008) Followership: How followers are creating change and changing leaders. Boston: Harvard Business School Press

Kelley RE. (2008) Rethinking followership. The art of followership: How great followers create great leaders and organizations. San Francisco, Jossey-Bass

McKimm J, Forrest K (2010) Using transactional analysis to improve clinical and educational supervision: the Drama and Winner's triangles. Postgraduate Medical Journal, online first 3 April 2010 doi: 10.1136/pgmj.2009.093310

McKimm J \& Held S (2009) In: J. McKimm, \& K. Phillips (Eds.) The emergence of leadership theory: From twentieth to the twenty-first century Leadership and Management in Integrated Services Creating Integrated Services (pp. 1-19). Exeter: Learning Matters Ltd.

NHS Leadership Academy (2013). The Healthcare Leadership Model, version 1.0, Leeds: NHS Leadership Academy. Available at https://www.leadershipacademy.nhs.uk/resources/healthcareleadership-model/ (accessed on 4/8/2019)

Sivan M, McKimm J, Held S (2011) Can an understanding of transactional analysis improve postgraduate clinical supervision? British Journal of Hospital Medicine 72(1), 44-48

Stewart I, Joines V (1987) TA Today: A New Introduction to Transactional Analysis. Lifespace Publishing, Nottingham, UK, and Chapel Hill, NC, USA 
The Kings Fund (2011). The Future of Leadership and Management in the NHS: No more Heroes. Report from The King's Fund Commission on Leadership and Management in the NHS. Available at: https://www.kingsfund.org.uk/publications/future-leadership-and-management-nhs $\quad$ (accessed $11 / 06 / 2019)$

Weihrich H (1979) How to change a leadership pattern. Manage Rev 68(4): 26-28, 37-40.

West M, Eckert R, Collins B, Chowla R. (2017) Caring to change: how compassionate leadership can stimulate innovation in health care. London: The King's Fund. 2017 May.

\section{KEY POINTS}

- effective communication is central to the provision of high quality health care and maintaining good relationships;

- transactional analysis models can provide insight into communication difficulties;

- both leaders and followers can learn to communicate more appropriately when they understand how ego-states operate in practice;

- being able to operate in 'adult' ego state aligns with the most effective leadership styles for the workplace. 